\title{
PENGGUNAAN PUPUK ORGANIK TABUR (POT) DAN ZEOLIT UNTUK MENINGKATKAN PERTUMBUHANDAN HASIL TANAMAN MENTIMUN (Cucumis sativus $\mathbf{L}$.)
}

\author{
Yefriwati $^{1}$, Ziela Delvira ${ }^{2}$ \\ ${ }^{1}$.Staf Pengajar Program Studi Budi Daya Tanaman Hortikultura, Jurusan Budidaya Tanaman \\ Pangan, Politeknik Pertanian Negeri Payakumbuh \\ ${ }^{2}$.Mahasiswa Program Studi Budi DayaTanaman Hortikulktura, Jurusan Budidaya Tanaman \\ Pangan, Politeknik Pertanian Negeri Payakumbuh \\ Jalan Raya Negara KM.7 Tanjuang Pati, Koto Tuo, Harau, Kabaupaten Lima Puluh Kota, \\ Sumatra Barat, 26271 \\ e-mail : yefriwati@ymail.com/yefriwati@politanipyk.ac.id
}

\begin{abstract}
ABSTRAK
Mentimun (Cucumis sativus L.) merupakan salah satu jenis tanaman sayur tropis yang banyak dikembangkan di Indonesia dan memiliki nilai jual yang cukup tinggi. Salah satu upaya untuk mendukung pengembangan budidaya mentimun yaitu dengan menggunakan pupuk organik tabur (POT) dan Zeolit. POT merupakan pupuk organik tabur yang berasal dari bahan organik yang banyak mengandung hara makro (N,P, dan $\mathrm{K}$ ) dan hara mikro (Ca dan $\mathrm{Mg}$ ). Pengaruh bahan organik terhadap sifat fisik tanah adalah terhadap peningkatan porositas tanah. Zeolit sering digunakan sebagai pembenah tanah.Tujuan percobaan ini yaitu (1) mengoptimalkan produksi tanaman mentimun dengan menggunakan pupuk organik tabur (POT) dan zeolit (2) mengetahui pengaruh penggunaan pupuk organik tabur (POT) dan zeolit yang terbaik terhadap pertumbuhan dan hasil tanaman mentimun

Kegiatan percobaan tugas akhir ini telah dilakukan selama 3 bulan dari bulan Maret sampai Mei 2019 yang bertempat di kebun percobaan PT. Indmira, Sleman, Yogyakarta.Alat yang digunakan, cangkul, seedbed, meteran, ember, gelas akua, alat tulis (spidol, pena dan rol), kaleng bekas. Bahan yang dibutuhkan adalah bibit mentimun, NPK mutiara, MPPH, zeolit, Pupuk POT, ajir, semat (bambu), dolomit, arang, sekam bakar, cocopeat, tali rafia, kantong plastik.Parameter yang diamatiya itu tinggi tanaman, jumlah duan, lebar daun, awal muncul bunga dan hasil.

Berdasarkan hasil pengamatan menggunakan kombinasi pupuk organik tabur (POT) dan zeolit dapat mengoptimalkan pertumbuhan tanaman mentimun dilihat dari tinggi tanaman (21,35 $\mathrm{cm})$, jumlah daun $(9,75$ helai), lebar daun $(17,10 \mathrm{~cm})$, awal muncul bunga $(2,70 \mathrm{buah})$, dan produksi $(13,989 \mathrm{gr})$, dan dalam budidaya tanaman mentimun disarankan menggunakan kombinasi pupuk organik tabur (POT) dan zeolit.
\end{abstract}

Kata kunci: Pupuk Organik Tabur (POT), Zeolit, Tanaman Mentimun, Sekam bakar

\section{PENDAHULUAN}

Mentimun (Cucumis sativus L.) merupakan salah satu jenis tanaman sayur tropis yang banyak dikembangkan di Indonesia dan memiliki nilai jual yang cukup tinggi. Mentimun tidak hanya dikomsumsi sebagai sayuran tetapi, juga digunakan sebagi ramuan obat tradisional. Mentimun biasanya disajikan dalam bentuk olahan segar, seperti acar, salad, jus dan lalapan.

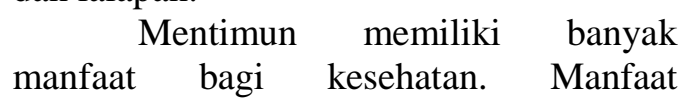

mentimun bagi kesehatan antara lain dapat menurunkan tekanan darah tinggi, anti kanker, obat diare, tipus, memperlancar buang air kecil, dan sebagai obat sariawan. Selain itu, mentimun juga bermanfaat untuk detoksifikasi atau peluruh racun dari dalam tubuh, dan dapat digunakan untuk perawatan kulit, mengobati sakit gigi dan gusi, diabetes, membunuh cacing pita serta perawatan ginjal (Mikail dan Candra, 2011).

Nilai gizi mentimun cukup baik karena sayuran buah ini merupakan 
sumber vitamin dan mineral. Kandungan zat gizi yang terdapat pada mentimun per 100 gram adalah energi 12 kalori, protein $0.7 \mathrm{~g}$, lemak $0.1 \mathrm{~g}$, karbohidrat $2.7 \mathrm{~g}$, kalsium $10 \mathrm{mg}$, fospor $21 \mathrm{mg}$, besi $0.3 \mathrm{mg}$, vitamin A $0 \mathrm{RE}$, vitamin C $8.0 \mathrm{mg}$ dan vitamin $\mathrm{B} 10.3 \mathrm{mg}$, thiamin $0,03 \mathrm{mg}$, riboflavin $0,04 \mathrm{~g}$, niacin $0,2 \mathrm{mg}$ (Supena, 2001).

Produksi mentimun secara nasional terus mengalami penurunan dalam kurun waktu tertentu, produksi mentimun pada tahun 2014 berproduksi 477.976 ton, pada tahun 2015 berproduksi 447.677 ton, pada tahun 2016 berproduksi 430.201 ton. Kebutuhan akan mentimun terus meningkat seiring dengan kesadaran masyarakat untuk mengkonsumsi sayuran (BPS, 2016).

Produksi mentimun secara nasional masih rendah yakni 3.5 ton/ha sampai 4 ton/ha. Menurut Supena (2001), mengatakan rendahnya produktivitas tanaman mantimun di Indonesia disebabkan oleh beberapa faktor diantaranya faktor iklim, teknik bercocok tanam seperti pengolahan tanah, pengairan, adanya serangan hama dan penyakit serta pengunaan pupuk an organik yang berlebihan.

Salah satu upaya yang dapat dilakukan untuk meningkatkan pertumbuhan dan produksi tanaman mentimun dengan cara memberikan pupuk organik tabur (POT) dan zeolit. POT merupakan pupuk organik tabur yang berasal dari bahan organik yang banyak mengandung hara makro (N,P, dan $\mathrm{K}$ ) dan hara mikro ( $\mathrm{Ca}$ dan $\mathrm{Mg}$ ).Bahan organik mempunyai pengaruh terhadap sifat fisik, kimia dan biologi tanah. Selain itu bahan organik juga berperan terhadap kebutuhan hara dan ketersediaan P. Pengaruh bahan organik terhadap sifat fisik tanah adalah terhadap peningkatan porositas tanah. Menurut Sedjati (2006), penambahan bahan organik akan meningkatkan pori total tanah dan menurunkan berat volume tanah, selain itu penambahan organik juga akan meningkatkan kemampuan tanah menahan air Zeolit Soil treatment ini sering disebut dengan pembenah tanah, pembenah tanah adalah bahan alami atau sintetik mineral untuk menanggulangi kerusakan tanah. Pembenah tanah dapat digunakan untuk mempercepat pemulihan kualitas tanah. Penggunaan pembenah tanah utamanya ditujukan untuk memperbaiki kualitas fisik,kimia, dan biologi tanah.

Berdasarkan permasalahan tersebut telah dilakukan percobaan tugas akhir dengan judul "Penggunaan Kombinasi Pupuk Organik Tabur (POT) Dan Zeolit Untuk Meningkatkan Pertumbuhan Dan Hasil Tanaman Mentimun (Cucumis sativus L.) di PT. Indmira Yogyakarta".

\section{Tujuan}

Tujuan percobaan ini adalah:

1. Mengatahui pertumbuhan dan hasil tanaman mentimun dengan menggunakan pupuk organik tabur (POT) dan Zeolit

2. Mengetahui pengaruh penggunaan pupuk organik tabur (POT) dan Zeolit yang terbaik terhadap pertumbuhan dan hasil nmentimu

\section{METODE PELAKSANAAN \\ Waktu dan Tempat}

Pelaksanaan kegiatan tugas akhir telahdilakukan dari 23 Maret 2019 sampai 4 Mei 2019. Kegiatan dilaksanakan di kebun percobaan PT. Indmira dengan ketinggian 600 meter dari permukaan laut.

\section{Alat dan Bahan}

Alat yang digunakan, cangkul, seedbed, meteran, ember, gelas akua, papan pengamatan, alat tulis (spidol, pena dan rol), kaleng bekas. Bahan yang dibutuhkan adalah bibit mentimun, NPK mutiara, MPPH, pembenah tanah (zeolit), Pupuk POT, ajir, semat (bambu), dolomit, arang, sekam bakar, cocopeat, tali rafia, kantong plastik.

\section{Perlakuan}

Percobaan ini menggunakan 4 perlakuan dengan 2 ulangan yaitu :
A. Kontrol 
B. Zeolit (sebagai pembenah tanah)

C. Pupuk organik tabur (POT)

D. Zeolit + pupuk organik tabur (POT)

\section{Prosedur Pelaksanaan Penyemaian Benih}

Media yang digunakan adalah cocopeat dan sekam bakar dengan perbandingan 1:1 kemudian diaduk sampai merata. Media yang sudah homogen dimasukkan kedalam tempat penyemaian (seedbed). Kemudian benih mentimun disemai 50 per seedbed, dengan jumlah seedbed sebanyak 3 buah. Biji yang ditanam biji yang sehat. Penyemaian dilakukan menggunakan pinset agar ke sterilannya terjaga. Kemudian bibit yang sudah ditanam disiram sampai media sedikit lembab dan dibawa ke green house.

\section{Pengolahan Lahan}

Pengolahan tanah dilakukan selama 2 hari yang bertujuan memperbaiki kondisi tanah menjadi lebih baik bagi pertumbuhan tanaman mentimun.

\section{Pembuatan Bedengan}

Pembuatan bedengan dilakukan setelah pengolahan tanah selesai dengan kondisi tanah remah dan halus selama satu hari. Bedengan dibuat dengan lebar 120 $\mathrm{cm}$, tinggi $30 \mathrm{~cm}$ dan panjang bedengan 2 meter dengan 8 bedengan.

\section{Pemasangan Mulsa}

Pemasangan mulsa plastik hitam perak (MPHP) dilakukan tujuh hari sebelum tanam dengan cara menarik kedua ujung MPHP ke masing-masing ujung bedengan arah memanjang, dikuatkan dengan pasak bilah bambu berbentuk "U" yang di pasangkan di setiap sisi bedengan. Tarik lembar MPHP ke bagian sisi kiri kanan bedengan hingga kelihatan merata menutup permukaan bedengan, kemudian kuatkan dengan bilah bambu pada setiap jarak $40-50 \mathrm{~cm}$. Mulsa plastik perak hitam dipasang pada siang hari pada saat terik matahari.

\section{Pembuatan Lubang Tanam}

Kegiatan pembuatan lubang tanam dilakukan dengan cara melobangi mulsa, dengan menggunakan kaleng bekas y diisi dengan arang yang dipanaskan. J: tanam yang digunakan adalah 50 x $60 \mathrm{c}$

\section{Pemberian Pupuk Dasar}

Pupuk dasar yang digunakan yaitu pupuk NPK mutiara 16:16:16 dan kapur dolomit, yang diberikan 1 gram/tanaman pada umur 4 minggu setelah tanam.

\section{Pemangkasan}

Pemangkasan dilakukan pagi hari pada tanaman berumur 3 minggu sampai 4 minggu setelah tanaman. Bagian tanaman yang dipangkas adalah daun yang rimbun dan cabang wiwilan. Pemangkasan bertujuan untuk merangsang terbentuknya cabang baru yang produktif menghasilkan bunga dan buah sekaligus mempercepat pembuahan, maka tanaman mentimun yang terlalu rimbun perlu dipangkas beberapa helai daunnya.

\section{Penyiangan}

Penyiangan dilakukan pada tanman berumur 2 minggu setelah tanam. Penyiangan dilakukan dengan cara membersihkan gulma disekitar tanaman tumbuh, dan untuk penyiangan diantara bedengan (drainase) dilakukan dengan menyemprotkan roundup. Penyiangan dilakukan dengan tujuan mencegah terjadinya persaingan antar tanaman dan gulma dalam penyerapan unsur hara, air dan cahaya matahari.

\section{Pengendalian Hama dan Penyakit}

Pengendalian hama dan penyakit dilakukan dengan cara preventif (pencegahan) dan kuantitatif (pengendalian ) 2 minggu setelah tanam dan berakhir 1 minggu sebelum panen. Pengendalian dilakukan secara mekanis, fisik maupun dengan pestisida. Hama yang menyerang yaitu ulat dan oteng-oteng. Hama otengoteng menyerang pada awal tanam. 
Pengendalian yang dilakukan yaitu memberi sedotan dibagian pangkal tanaman, sedangkan hama ulat merang pada daun dan pucuk tanaman dengan memakan daging daun sehingga hanya menyisakan tulang daun. Pengendalian yang dilakukan yaitu dengan dilakukannnya penyemprotan pestisida dengan merek dagang convidor, dosis yang digunakan 3 gr per 10 liter air

\section{Pengamatan}

dilakukan yaitu

Parameter pengamatan yang

1. Tinggi Tanaman $(\mathrm{cm})$

Tinggi tanaman diamati mulai satu minggu setelah tanam sampai dua minggu setelah tanam dengan cara diukur dari pangkal batang sampai ujung daun tertinggi dengan menggunakan penggaris. Sampel yang diamati sebanyak 10 tanaman per perlakuan.

2. Jumlah Daun (helai) dan lebar daun (cm)

Jumlah daun tanaman diamati mulai satu minggu setelah tanam sampai empat minggu setelah tanam dengan cara dihitung dari seluruh daun yang sudah terbuka sempurna. Sampel yang diamati sebanyak 10 tanaman per perlakuan.

3. Lebar daun

Lebar daun tanaman diamati mulai satu minggu setelah setelah tanam sampai tiga minggu setelah tanam dengan cara diukur pada daun yang terlebar dengan menggunakan meteran. Sampel yang diamati sebanyak 10 tanaman per perlakuan.
4. Awal Muncul Bunga (minggu)

Jumlah bunga tanaman diamati pada awal muncul bunga pada umur empat minggu setelah tanam dengan cara yang dihitung hanya bunga betina yang bakal jadi buah. Sampel yang diamati sebanyak 10 tanaman per perlakuan

5. Produksi

Produksi mentimun didapat setelah mentimun berumur 35 hari setelah tanam dan hasil panennya sesuai perlakuannya. Sampel yang diamati sebanyak 10 tanaman per perlakuan

\section{Panen dan Pascapanen}

Panen buah mentimun dilakukan pada umur 35 hari setelah tanam. Panen dilakukan 2 kali dalam satu minggu. Panen dilakukan dengan memotong tangkai buah menggunkan gunting atau pisau yang tajam. Ciri-ciri mentimun yang dipanen yaitu berukuran besar yang masih ada durinya dan panjang buah antara $10-15 \mathrm{~cm}$, hasil panen yang diperoleh ditimbang berdasarkan sampel masing-masing.

\section{HASIL DAN PEMBAHASAN \\ Hasil \\ Pertumbuhan Vegetatif}

Hasil dari pertumbuhan vegetatif pupuk organik tabur (POT) dan zeolit untuk meningkatkan pertumbuhan dan hasil tanaman mentimu dengan parameter pengamatan tinggi tanaman $(\mathrm{cm})$, jumlah daun (helai), lebar daun $(\mathrm{cm})$ dan awal muncul bunga (buah) dapat dilihat pada tabel 2 .

Tabel 2. Pengamatan Pertumbuhan Vegetatif dan generatif

\begin{tabular}{lcccc}
\hline \multirow{2}{*}{ Perlakuan } & \multicolumn{4}{c}{ Parameter Pengamatan } \\
\cline { 2 - 5 } & $\begin{array}{c}\text { Tinggi } \\
\text { Tanaman }(\mathrm{cm})\end{array}$ & $\begin{array}{c}\text { Jumlah Daun } \\
\text { (helai) }\end{array}$ & $\begin{array}{c}\text { Lebar Daun } \\
(\mathrm{cm})\end{array}$ & $\begin{array}{c}\text { Awal Muncul } \\
\text { Bunga (jumlah }\end{array}$ \\
\hline Kontrol & 17,98 & 8,70 & 14,45 & 1,25 \\
Zeolit & 18,00 & 8,90 & 14,60 & 1,55 \\
POT & 19,85 & 9,70 & 16,10 & 1,70 \\
POT+ & 21,35 & 9,75 & 17,10 & 2,70 \\
Zeolit & & & & \\
\hline
\end{tabular}

Berdasarkan Tabel 2 diketahui bahwa pertumbuhan mentimun yang paling 
baik dengan menggunakan pupuk organik tabur yang ditambahkan dengan zeolit yaitu dengan tinggi tanaman $21,35 \mathrm{~cm}$, jumlah daun 9,75 helai, lebar daun 17,10 $\mathrm{cm}$ dan awal muncul bungan 2,70 buah

\section{Pertumbuhan Generatif}

Hasil pengamatan terhadap hasil produksi mentimun dengan menggunakan pupuk organik tabur (POT) dan Zeolit dapat dilihat pada tabel :

Tabel 3. Pengamatan Hasil Tanaman Mentimun

\begin{tabular}{lc}
\hline \multicolumn{1}{c}{ Perlakuan } & Hasil Produksi (gr) \\
\hline Kontrol & 8.784 \\
Zeolit & 10.059 \\
POT & 13.691 \\
POT+ Zeolit & 13.989 \\
\hline
\end{tabular}

Hasil pengamatan diatas dapat diketahui bahwa hasil produksi terbanyak terdapat pada perlakuan pupuk organik tabur (POT) dan Zeolit dengan hasil 13.989 gr. Hasil terbanyak kedua pada perlakuan pupuk organik tabur (POT) hasil 13.691 gr. Hasil terbanyak ketiga pada perlakuan Zeolit dengan jumlah hasil 10.059 gr serta hasil yang paling sedikit terdapat pada perlakuan kontrol yaitu 8.784 gr.

\section{Pembahasan}

Pelaksaaan pengalaman kerja praktik ini dilakukan di kebun percobaan PT. INDMIRA Sleman,Yogyakarta pada bulan Maret sampai April 2019, dengan mengunakan kombinasi pupuk organik tabur (POT) dan Zeolit untuk mengoptimalkan produksi tanaman mentimun. Dari hasil panen yang telah didapat perlakuan pupuk organik tabur yang dikombinasikan dengan POT + Zeolit yang terbaik yaitu $13.989 \mathrm{gr}$.

Pertumbuhan tinggi, jumlah daun dan lebar daun tanaman mentimun yang rendah terlihat pada perlakuan kontrol. Hal ini dikarenakan perlakuan kontrol ini tidak ada penambahan pupuk organik yang dapat memperbaiki sifat fisik, biologi dan kimia tanah. Pertumbuhan tinggi, jumlah daun dan lebar daun tanaman mentimun lebih tinggi pada perlakuan yang diberikan pupuk organik tabur (POT) yang dikombinasikan dengan Zeolit. Menurut (Damanik, 2010) penambahan bahan organik dapat meningkatkan agregasi tanah, memperbaiki aerase dan perkolasi serta melepaskan ion-ion dan logam dalam tanah sehingga dapat tersedia didalam tanah dan diserap tanaman. Hal ini dikarenakan didalam pupuk organik tabur (POT) dan zeolit terdapat bahan organik yang dapat memperbaiki sifat fisik, kimia dan biologi tanah.

Pengamatan generatif awal muncul bunga terbaik terdapat pada perlakuan pupuk organik tabor (POT) yang dikombinasikan dengan zeolit. Awal muncul bunga dipengaruhi oleh faktor internal dan faktor eksternal antarnya lingkungan. Faktor lingkungan yang sangat berpengaruh adalah ketinggian tempat yang berkaitan dengan suhu. Menurut Zulkarnain(2013), tanaman mentimun dapat tumbuh dengan baik antara dataran rendah sampai dataran sedang kisaran 200-800 meter diatas permukaan laut.

Produksi tanaman mentimun di pengaruhi oleh tinggi tanaman,lebar daun dan jumlah daun tanaman dan jumlah bunga. Pertumbuhan tanaman yang baik pada fase vegetatif maka akan berpengaruh pada fase generatif. Menurut Harjadi(2002), fase vegetatif tanaman berhubungan dengan tiga proses penting yaitu pembelahan sel, perpanjang sel, dan deferensiasi sel. Hasil pengamatan percobaan yang dilakukan bahwa pupuk POT yang dikombinasikan dengan zeolit merupakan pupuk terbaik untuk pertumbuhan dan produksi tanaman mentimun dibandingkan dengan penggunaan pupuk POT tampa ditambahkan dengan zeolit dan juga kontrol. Hal ini disebabkan karena pupuk POT banyak mengandung hara makro dan hara mikro yang dibutuhkan oleh tanaman sehingga dapat memperbaiki kondisi tanah .Menurut Suriadikarta, 2006 bahwa fungsi utama dari zeolit sebagai bahan pembenah tanah yang dapat meningkatkan kapasitas tukar kation (KTK) tanah; peningkatannya tergantung jenis tanah, jumlah 
penambahan zeolit, dan jenis mineral zeolit (Suriadikarta, 2006).

\section{Kesimpulan}

KESIMPULAN DAN SARAN

Penggunaan kombinasi pupuk organik tabur (POT) dan zeolit dapat meningkatkan pertumbuhan tanaman mentimun dilihat dari tinggi tanaman $(21,35 \mathrm{~cm})$, jumlah daun $(9,75$ helai), lebar daun $(17,10 \mathrm{~cm})$, awalmunculbunga $(2,70$ buah), dan produksi (13,989 gr).

\section{Saran}

Dari hasil percobaan diatas disarankan sebaiknya dalam budidaya tanaman mentimun menggunakan kombinasi pupuk organik tabur (POT) dan zeolit

\section{DAFTAR PUSTAKA}

Badan Pusat Statistik [BPS]. 2016. Produksi sayuran di Indonesia : Jakarta. Badan Pusat Stati ${ }^{+1 \text {. }}$ Nasional. Jakarta.

Cahyono,B. 2006. Timun Aneka Ilmu. Semaramg. Hal4, 8, 10, dan27

Dariah, A., Nurida N.L., dan Sutono. 2007. Formulasi bahan pembenah untuk rehabilitasi lahan terdegradasi. Disampaikan pada Seminar Sumberdaya Lahan dan Lingkungan. Bogor, 7-8 Nopember 2007.

Megahwati, I. 2009. Pengaruh Waktu Pemberian dan Dosis Pupuk Kandang Ayam terhadap Pertumbuhan dan Produksi Jagung pada Berbagai Dosis Pupuk Urea. IPB. Bogor

Mikail, B. dan A. Candra.2011.manfaat tersembunyi mentimun. Kompas. Jakarta

Saragi, S. 2008. Pengaruh Dosis Pupuk Kandang dan Dosisi Kalium Terhadap Pertumbuhan dan Produksi Tanaman Mentimun. Skripsi. DeperTeman Budidaya Pertanian. Fakultas Pertanian, Institut Pertanian Bogor. Bogor. 30 hal.

Sutanto, R. (2002). Pertanian Organik. Yogyakarta: Penerbit Kanisius
Suwardi. 2007. Pemanfaatan zeolit untuk perbaikan sifat-sifat tanah dan peningkatan produksi Peranian. Dipresentasikan pada Semiloka Pembenah Tanah Menghemat Pupuk,Mendukung Peningkatan Produksi beras. Direktorat Jenderal Pengelolaan Lahan dan Air, Departemen Pertanian bekerjasama dengan Konsorsium Pemebenah Tanah Indonesia. Jakarta 5 April 2007.

Damanik, M. M. B., Bachtiar, E.H., Fauzi., Sariffudin dan Hanum, H. 2010. Kesuburan Tanah dan Pemupukan. USU Press, Medan

Harjadi, S.S. 2002. Pengantar Agronomi. PT. Gramedia Pustaka Utama. Jakarta. $195 \mathrm{hlm}$

Zulkarnain. 2013. Budidaya tanaman tropis. Bumi aksara. Jakarta. 